Zusammenfassung. Der Film gibt eine kurze Einführung in die Technik der Mikrogefäßchirurgie. Es werden die notwendigen Instrumente und sonstige Ausrüstung vorgestellt. Durch drei klinische Fälle wird das operative Vorgehen sowie die Indikation veranschaulicht. Unter Benutzung eines Leistentransplantates wird ein Defekt über der Tibia und auf dem Schädel gedeckt. Mit einem Gewebeblock vom Fußrücken wird eine Transplantation zum Handteller ausgeführt.

Schlüisselwörter: Mikrogefäßchirurgie - Freie Transplantation.

\title{
152. Kontinenzoperation bei Atresia ani vestibularis im Erwachsenenalter
}

\author{
A. Zängl \\ II. Chirurgische Abteilung, Landeskrankenanstalten Salzburg, Österreich
}

\section{An Operation for the Establishment of Continence in the Adult with Fourchette Anus}

Summary. Adult women with a history of unsuccessful operation(s) for Fourchette anus in babyhood should be re-examined with the aid of electromyography to find whether sphincter muscles and a muscular pelvic floor are present: the presence of the latter justifies a pull-through type procedure, which is shown in detail. Results in two recent cases proved to be extremely gratifying.

Key words: Atresia ani vestibularis - Continence, surgical attainment of - Electromyography.

Zusammenfassung. Patientinnen, welche wegen kongenitaler Atresia ani vestibularis erfolglos im Säuglingsalter operiert wurden, sollten elektro-myographisch untersucht werden. Falls contractile Beckenboden- und Schließmuskulatur nachweisbar sind, lassen sich mit einer Durchzugsoperation, deren Technik eingehend beschrieben wird, befriedigende Kontinenz und ein an normaler Stelle gelegener Anus erzielen.

Schlüsselwörter: Atresia ani vestibularis - Elektromyographie - Kontinenzoperation.

153. Zusammenfassung nicht eingereicht.

\section{Die subcutane Mastektomie, Indikation und Technik}

\author{
H. Bohmert und W. Haas \\ Chirurgische Klinik der Universität München
}

\section{Subcutaneous Mastectomy: Indications and Technique}

Summary. The indications applied by the authors for subcutaneous mastectomy are (1) atypical proliferating breast disease, because the risk of cancer is 31.4 percent higher than in other patients, (2) Ca in situ, because this is regarded as a true precursor of invasive cancer, and (3) recurrent fibro- 